\title{
アムステルダム，ムゼウムプレインに見る首都における文化中心としての 都市空間に関する20世紀後半の議論
}

\section{THE MUSEUMPLEIN IN AMSTERDAM, THE DISCUSSION ON THE LANDSCAPE OF A CULTURAL CENTER IN THE CAPITAL IN THE SECOND HALF OF TWENTIETH CENTURY}

\author{
田村 望* \\ Nozomi TAMURA
}

\begin{abstract}
The Museumplein in Amsterdam is indicated one of a potential contact points to load the Amsterdam brand. This place was born by the movement to gain the impressive cityscape as a European Modern Capital in the late ninetieth century. After the discussion on the meaning and the design for more than one century, this place was opened as the Museumplein at the end of the twentieth century. The center of the discussion was sifted from elite and bourgeois to civilized masses after the Second World War. The Constant's New Babylon become popular in the 1960s and his antipathy toward both avant-garde art and functional architecture which he regarded as elitist attempt to rob play and creativity from "the mass" had gained attention. The character as a cultural center in the city was intensified in the 1970s to 1980 s. The possibilities of cycling and rambling and the cultural function of the free manifestation were required. The newspapers heated up the discussion. The final landscape design of the Museumplein was evaluated because of the "Emptiness", the "Neutrality" and the preservation of the developed character by the early second half of the 20 th century. This place, the Museumplein, gains the centrality and is not any more the back yards of the cultural institutes. No institute can be a zenith there. The new national cultural public space is require to equally accept the various level of the urban elements and activities and return them to the the city again.
\end{abstract}

Keywords: the Netherlands, Urban Landscape Design, Constant's New Babylon, Museum Square オランダ、都市のランドスケープデザイン、コンスタンの新バビロン、ミュージアム広場

1. はじめに

\section{$1-1$. 研究の目的}

アムステルダムの中心部にあるムゼウムプレイン 1) (以下 $\mathrm{AMP}$ 。 Fig. 1) は、現在アムステルダムの観光と文化をアピールする拠点の 上位に位置づけられている2。よく広場らしい広場が無いと表現さ れるオランダの都市であるが、AMP は開放的なオープンスペースで、 国民的、国際的な行事やデモ会場にもなり、年間を通じて使用され る国民的都市空閒である。AMPは19 世紀後期にその端を発し、当 時のオランダを代表する建築文化財に囲まれた場所だが、19 世紀に 多くの欧州の首都が求めた近代的都市の記念碑性の表現は欠如して いる。この場所がどうあるべきかの議論は、19 世紀末から約 1 世紀 に渡り続いた。その末 AMP は 1999 年にデンマークを拠点にするラ ンドスケープアーキテクト、アンデルソン (Sven-Ingvar Andersson) の設計でオープンした。20世紀末、新ミレニアムへ向けての文化施 設の改装を含むこの場所の改装·更新計画では、AMPのランドスケー プデザインが最重要視された。この場所に提案されたほとんどの計 画は実現しなかったが、建築運動、都市化、造園文化の相互関係の 中で展開するオランダ近現代ランドスケープデザインの変遷を見る 端緒としても興味深い対象である ${ }^{3)}$ 。19 世紀後期と 20 世紀後半の提 案や議論、結果としての AMP を見ると都市の文化中心的空間に対す る考え方、求める象徵性、表現方法などが変化する。本研究は 1 世 紀以上に渡るこの場所の議論の過程を明らかにしながら、この場所 の意味や文化を司る都市空間に求められるものが、どのような社会

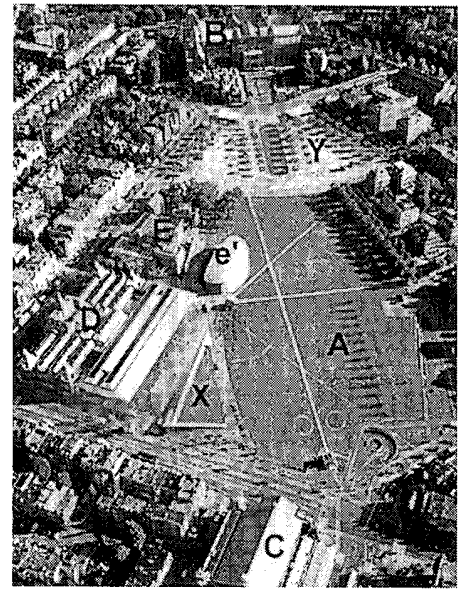

Fig. 1 ムゼウムプレインの 鳥瞰写真 2006 年 (ステイデリック. ムゼウム拡張計画案部分含む) $B$ 方向が北、C方向が南。 A. ムゼウムプレイン (AMP) 1999 年開園 B. 国立博物館 (RM) 1885 年開館 C. コンセルトヘボウ (CG) 1888 年開館 D.ステイデリック・ムゼウム (SMA) 1895 年開館

E.ファン・ゴッホ美術館 (VGM) 1973 年開館 e'.ファン・ゴッホ美術館 (VGM) 新棟 1999 年開館 X.ドンキーイヤー Y. 美術館の小さな森 *本論文中の図版の記号 A， B， C, D, $E, e^{\prime}, X, Y$. は上記の文化施設を示す。

状況や芸術的背景によって変化し、その何が受け継がれ、AMP のデ ザインに反映されたのかを明らかにすることを目的としている。前 稿 ${ }^{4)}$ では、この空間の在り方の議論を、アムステルダムに欧州近代 首都としての文化的空間を獲得させようという動きと合わせて 19 世 紀後期を中心に考察した。本稿はこの場所の在り方の議論が再燃し た 20 世紀後半に注目する。19 世紀的概念では市民と認められなかっ た人々を含め大大衆 5) が、都市における建築や都市景観の決定に関 与し始めることにより、議論の拡大と決定プロセスにも変化がある と考えられる。20世紀後半のこの議論がどのように展開し、どのよ うな最終的な計画に繋がったのかを明らかにすることを目的とする。
* 早稲田大学理工学総合研究センター 客員研究員・工修(早稲田大学),

人文社会科学修士 (ライデン大学)
Visiting Researcher, Advanced Research Institute for Science and Engineering of Waseda University, M. Eng. (Waseda University), M. Arts (University Leiden) 


\section{$1-2$. 既往研究 - 研究方法}

20 世紀後半については、まとまった研究はみられないが、1866年 から 1952 年までのこの場所への主要な提案についてはランドスケー プアーキテクトのエベリンクらが『ムゼウムプレイン 1866-1988』6) に図面を集めている。また、この場所の注目度は高く、デザイン・芸 術系雑誌『シミーラークルム』7) は AMP 計画特集を組み、美術と 文化の専門季刊誌『ヨングホラント』8) も特集でこの場所の歴史の 概観とアンデルソン案をとりあげた。その他の建築や美術系雑誌で も AMPに関する記事を見ることができる。また、この場所に提案さ れた計画案や文献資料収集の他、20 世紀後半は新聞報道にも多く取 り上げられており、それらの記事も資料として取り扱う ${ }^{9}$ 。さらに、 1988 年に AMP 競技設計を主催した NRC ハンデルスブラッド紙（以 下 NRC 紙) の記者のファン・ローイ (Max van Rooy) や、最終案に 慗がる基本概念の作成に関わったエベリンク、1993 年に組織された AMP 計画の諮問委員だったフールトセン (Rein Geurtsen) とクロース (Maarten Kloos)、アンデルソンの補佐として AMP の設計・監理にあ たったガル (Stefan Gall) らと面談し、それぞれの活動内容や目的、当 時の状況等に関しての聞き取りを行った ${ }^{10)}$ 。

\section{2.背景：近代的な首都への改造から脱柱状化社会へ \\ $2-1.19$ 世紀後期 : 場の発生}

この場所は、19 世紀後期のアムステルダム市拡張の必要性とパリ に触発された欧州近代都市たる首都改造の気運が高まった時期に生 じた。旧市壁、現在の歴史地区の南端 (Fig. 2) に国立博物館 (以下 $\mathrm{RM}$ )、コンセルトへボウ(以下 $\mathrm{CG}$ )、ステイデリック・ムゼウム（以 下 SMA） ${ }^{11)}$ という文化施設が建設され、その間の空間が現在 AMP と呼ばれる場所である。上記の文化施設はオランダを代表する文化 施設でありながら、個人の寄付や私的集団の先尊により設立された 点が共通する 12)。19 世紀後期には、AMP となる場所（以下 AMP 空 間) の開発指針が定まっていなかった。この空間は最初から計画され たのではなく、土地が安価だったことと、この地区が新たな文化中 心になるだろうという期待と目論見によって、各団体がそれぞれの 意図で建設した文化施設によって囲まれ、残った空間といえる ${ }^{13)}$ 。

\section{2-2.1950 年以前の AMP 空間の使用状況と提案の継続}

市の搪張に伴い、この地区が新たな中心となるだろうという意識 ができてきたようで、この地区に対しては 1860 年頃から市の作成し た案の他、競技設計の開催や市民や建築家等の個人による提案が残 されている。この場所への提案は、欧州近代首都たるべき文化施設 等の建設や都市形式、記念碑性の獲得を目指したことに始まり、次 第に近代都市の文化中心地区たる場所とは何か、ということ自体を 模索し始める ${ }^{14)}$ 。1 890 年頃からは、AMP 空間を建築物以外の広場

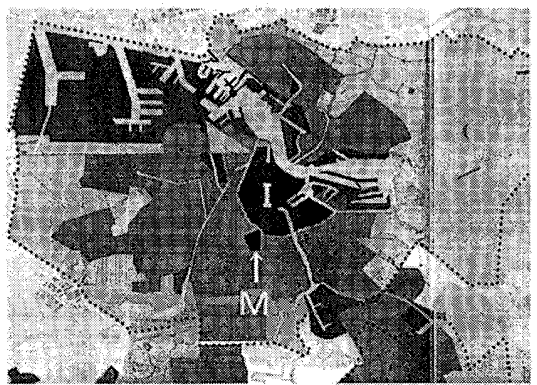

Fig. 2 アムステルダムにおけ る AMP の位置

Iの扇状の部分が 19 世紀前期 までのアムステルダム市内。M はAMPのあるムゼウム地区。 Mの部分は市壁跡地で、そこに 文化施設が建てられた。19世 紀後半からアムステルダム市は 周辺を編入しなから拡大した。 点線内が 1974 年のアムステル ダム市域。現在とほぼ同じ範囲。
や池、庭園といった新たな要素で占めようとする案も出てくる ${ }^{15)} 。$ 以前に、国立博物館から伸びる大通りを中心とした新市街区を提案 していたカイペルス（P.J.H Cuypers）も、1891 年に「都市には広場 が必要だ」といって広場案を作成した ${ }^{16)}$ 。1 890 年代から 1912 年頃は、 この周辺に高級住宅や学校等が建設されるが、AMP 空間には手はつ けられず 17)、結局どの提案も実現しなかった。ただし、都市計画を 決定せず、実行しなかっただけで、この場所は時代を通して積極的 に使用され続けた。19 世紀後期に代表されるのは、各種博覧会会場 で、またその頃からスケートを始めとする各種運動用地、女王の日 の祝賀行事の様な国家・国民的行事、子供達の遊び場、移動式遊園地 等にも使用された ${ }^{18)}$ 。デモ行動の中心地で、第一次世界大戦時には 抗議運動 ${ }^{19)}$ 鎮圧の為に軍警察がキャンプを張り、第二次世界大戦中 には燃料備蓄倉庫が建設され病院もあった ${ }^{20)}$ 。このように、季節的、 仮設的、有事の利用が積極的にされた。2つの大戦中は、オランダは 中立を保とうとした為に非常に困難な立場におかれ、経済は衰退し、 この場所一の提案もあまりみられない。しかし平和が訪れると再燃 する。例えば第 1 次世界大戦後の 1925 年にはワーグナー協会がこの 地に新オペラ座の競技設計を行い21)、第二次世界大戦以降もかなり の数の提案が、新聞や雑誌、同人誌等の様々な媒体に発表されてい たという22)。

\section{$2-3.1960$ 年代 : 脱柱状化、変容するオランダ社会}

20 世紀前半に非常に伝統的、保守的で遅れた国と呼ばれていた才 ランダは、1960年代に西ヨーロッパで最も大きな文化的変化を経験 したといわれる23)。19 世紀末から 20 世紀半ば頃までのオランダ社 会は、多様性を制度化した社会構造を示して「柱状化」と言い表さ れることが多い。政党が発達し始め、カソリック、プロテスタント、 自由、社会主義等の諸政党を中心に独自の社会集団が組織化され、 これらが並列して共存したことから「柱」と呼ばれる。各柱は互い の柱を犯さない限り寬容で、また指導者層によって、そのように配 慮し合うことで共存してきた ${ }^{24)}$ 。第 2 次世界大戦開戦直後、オラン ダはドイツの占領下となり政党や労働組合は解散させられる。その ことが抵抗活動や新たな社会組織を編成した。地下新聞が定期発行 され 25)、3大労組と雇用者団体は秘密裹に集まり、労使頂上団体の 常設機関である労働協会が設立された ${ }^{26)}$ 。各界の著名人や知識人が 中心に拘留されたスイント・ミヒールスヘテルの拘置所では戦後政 治構想に関する議論が行われ、党派や宗派を超えた政治改革を志向 した。この「改革派」は戦間期までの政治体制を突破し、柱状化社

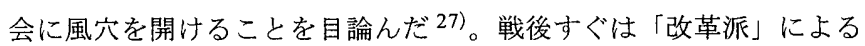
内閣が成立した。しかし、1945 年後半には既存政党が復活し、雇用 者団体や労働組合もほぼ復活した。1946 年の選挙で「改革」を揭げ た労働党は第 2 党に甘んじ、旧社会体制が崩れたわけではなかった 28)。しかし、60 年代になると、経済が上向きになり、世俗化と都市 化が急速に進行する。労組運動の他、既存団体に組織されない学生 運動、女性運動、反戦運動等が活性化する。「柱」も解体の危機にさ らされ、宗教に基盤をおいていた政党もその宗教色を薄めてゆく。 カソリックラジオ放送局やフォルクスクラント紙は柱から離脱した 29)。60 年代からは、ソフトドラッグの解禁、同性愛や性風俗への寛 容さ、安楽死の合法化等、一見並はずれた自由な社会とも見えるこ とが許容されるようになる。1980 年代に AMP となる場所の議論が 一般にまで搪がるまでには以上のような社会の変容があった。 


\section{3. 都市とは何か、誰のものか}

\section{3-1. 近代建築運動から都市計画の制度化へ}

オランダは近代建築運動や近現代の都市計画にお汀る先駆的な存 在として知られるが、その傾问の移り変わりも速く、AMS はその影 響を直に受けてきた都市でもある。オランダにおける 19 世紀的な欧 州近代都市を目指した首都建設は、18 世紀の経済的低迷を克服した 1860 年代後半からの約 30 年弱程のことである。これを受け継ぎなが らも、入れ替わりにオランダ 20 世紀近代都市建設活動が始まる。オ ランダでは、近代建築運動が既存権力への対抗や過去への反動とい う構図ではなく、むしろ行政と建築家が一体となって進めた。1902 年の住宅法の施行は、自治体が都市計画に主体的に関われるような 制度化を進めた ${ }^{30)}$ 。1900 年に市に助言を求められたベルラーへ (H.P. Berlage) はアムステルダム南の拡張計画に携わり 31 )、一建築家と市 の公共事業局 (Publieke Werken) が協働する都市計画が始まった。ま た、近現代建築運動における理論面でのオランダの果たした役割も 大きい。1928 年、ラ・サラでの第 1 回 CIAM(Congrès Internationaux d'Architecture Moderne 近代建築国際会議) の唯一の講演は、ベルラー へによるものだった ${ }^{32)}$ 。デ・ステイルやアムステルダム派、オップ バウ (Opbouw)デ・アフト (De8) 等のオランダ発の建築運動は海外 へも影響を及ぼした。ただし国内ではどれも1930 年代には解散する。 30 年代から 50 年代頃迄はファン・エーステレン (C. van Eesteren) を 代表とする機能主義の考え方が力を持っていた。彼は 1929 年にアム ステルダム市の公共事業局都市開発部の初代主任に就任したが（1958 年に退職)、これは市に都市計画を担う部署が初めて正式に組織さ れたことも意味する。彼は、CIAM の都市に関する活動にも積極的 に関わり、1931 年から 47 年にかけて議長に就任した ${ }^{33)}$ 。彼が率い る都市開発部は、1934 年にアムステルダム総合都市計画 (Algemeen Uitbreidingsplan van Amsterdam)を作成した。ベルラーへは、街区、街路、 広場などに注目し建築を延長して都市デザインに組み入れ、都市美 を最大の基準として都市の創造を試みた。ファン・エーステレンは、 現実の都市を構成する要素（工場、住宅地、交通網、スポーツ施設等） を分析抽出し、それらの集合した構造体として都市を捉え、美以上に、 調查や統計に根拠を求めた都市計画を行い 34)、構成要素の最適な分 布と配列によって都市を機能させるという、科学的な都市計画研究 と手法を実践し始めた。この流れは、現代オランダの社会経済・社 会地理的な調查に基づく国土空間計画に繫がる。彼は、アムステル ダムの都市計画に機能主義を全面的に採用し、住宅、職場、レクリエー ション、交通の 4 機能分離の考え方を反映させた ${ }^{35)}$ 。

\section{3-2. 都市創造の主体としての大衆}

しかし、1940 年代頃からは 20 世紀前半の近代建築運動に対する 批判や対抗が目立ち始める。ファン・アイク (A. van Eyck) 等の活動 があるが、やはり彼と親交のあった芸術家、コンスタント (Constant
Nieuwenhuys) によるユートピア都市概念に関する一連の作品「新バ ビロン」36) が 1960 年代に社会的流行を引き起こした。彼はファン・ アイクを通して建築関係者と交流があった。コブラ派の創設者の一 人であり、また芸術と政治の統一的実践を目指し、1957 から 72 年に かけてヨーロッパを中心に活動した国際団体シチュアショニスト・

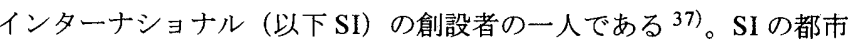
への取り組みは地図から始まった。「漂流」や「ずらし」という言葉 を多用し、人が場所や移動によって感じ取る都市への感覚や雾囲気 を記述しようと、切り取られた地図の断片を再構成した「心理地理 学」(Fig. 3) 等を試みた ${ }^{38)}$ 。コンスタントは前衛芸術や機能主義的 設計や建築を「大衆」から活動性や創造性を奪うエリート主義の試

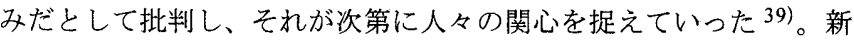
バビロン (Fig. 4)には、コンストラクションセクターやノマド・キャ ンプ等と呼ばれる立体作品や絵画、写真、コラージュ等の平面作品 と文章がある。チタン、ナイロン、針金、アクリル等、様々な素材 を組みあわせ、移動、交換、解体可能で柔軟な空間性を持つ構築物 の連続による都市が考えられた。新バビロンは、あらゆるものから 開放されて自律した新しい「木モ・ルーデンス(遊ぶ人)」40)の為 の、近未来都市として想定された都市である。そこは人間の行動を 規定するものは何もなく、柔軟な機能を持った多様な空間が連携し た人間主体の全く自由な都市とされる ${ }^{41)}$ 。コンスタントは誘われて GEAM (動く建築研究会) に参加したり、機関誌『アーキグラム第 5 号』 の特集「メトロポリス」への寄稿を依頼されるなど建築分野への影 響も大きかった ${ }^{42)}$ 。建築分野では、メガ・ストラクチャーや空中都 市へと進む傾向が見られる ${ }^{43)}$ 。しかし、コンスタントは 60 年代の終 わりに「知識人の間で新たな理想主義が起こることに危機感を覚え る」と述べ、この都市が今の社会で実際に建設されることの不可能 さを告白し44)、1974 年に最終展覧会を行った。

ところが、コンスタントの影響は建築や芸術分野にとどまらず、 一般社会の中でも展開した。1965 年のハーグでの新バビロンの展覧 会は成功を収め、その作品によって視覚的に印象づけられたその思 想は国内外に広く知られるようになった。ある新聞はその年を「コ ンスタント年」と呼び、また当時台頭していた新左派社会主義者の 1967 年宣言等にも影響する等、新バビロンは人々の心を捉え、その 思想が社会の中に拡がった ${ }^{45)}$ 。オランダの政治は 60 年代に左傾向化 するが、新左派社会主義者はその主張の 1 つに「文化の平等な取り 扱いりにる生活の質の向上を強調し、急進的な党になろうと模索 していた ${ }^{46)}$ 。新バビロンは都市の使用者である大衆が、都市創造に 関わる主体であり、権利を持つことを示し、強烈な残像として残し たといえるだろう。ケネディーは、コンスタントの個人的な影響力 は時と共に衰えたが「遊びに満ちた」自由な文化は 1960 年代後半の オランダで発展する一方だったと指摘している ${ }^{47) 。 ~}$

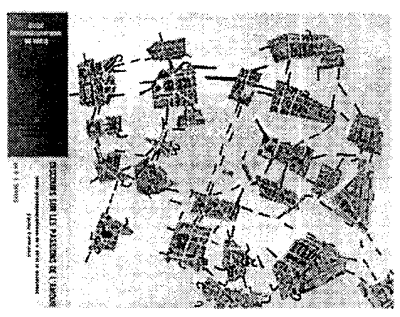

Fig. 3『パリの心理地理ガイド』表組

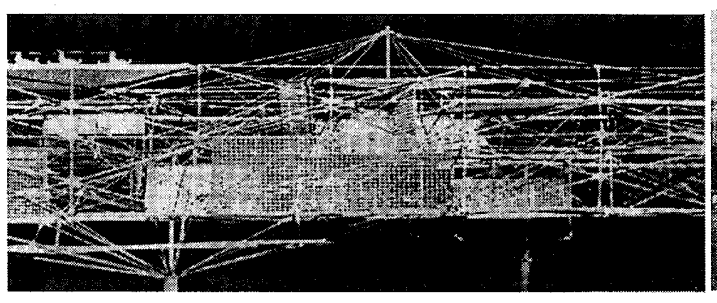

Fig. 4 コンストラクションセクター 部分 1959 年 新バビロンシリーズの例。他に、模型、絵画、写真の平面作品や文章等数多くの作品がある。 
1970 年代からは、都心再生として 19 世紀に建設された地区の撤去 と再開発が奨励されていた。これは、産業活性化の為に都心に企業 向けの土地の確保や自動車道等の都市交通網整備の必要性が考えら れていたことに加え、移民や若い世代による古い建築物の不法占拠 が横行しており政治的な要請でもあった ${ }^{48)}$ 。同時期にアムステルダ ムでは市民による都市開発行為の反対運動や改善要求も起こってい た。アムステルダム市役所は都市計画の全権を担っていたが、都市 空間設計技術のみが発展し、市民という主体不在の都市計画の実行 は烈しい抵抗を生み出していた為、1984 年にアムステルダム市は「 プラベラム」と呼ばれる都市開発計画に対する合意形成の為の意思 決定プロセスに関する内規を承認し、都市開発計画に際し、より透 明性のある計画と合意形成を模荣する ${ }^{49)}$ 。伝統的に協議に重きを置 く社会であるが、トップダウンから水平協議の時代へ移行する ${ }^{50) 。 ~}$

\section{4. 第 2 次世界大戦後の議論と文化中心性の強化}

\section{4-1. 機能主義に基づく都市間高速道路構想の実行と批判}

第 2 次世界大戦後、スヴィッアー (S. Switzer) が「場所の重要性を 再喚起して議論を起こすために」と言って 1 案を発表した ${ }^{51)}$ 。1952 年には、この場所の論議を拡大寸る引き金にもなった、ファン・エー ステレン率いる市の都市開発部の案が発表された。1952 年の市の提 案は、機能主義の考えに基づいたアムステルダムからの都市間高速 自動車道構想の一部で、1929年にファン・エーステレン他 3 名で発 表していた提案と基本的な考え方は変わっていない。1929年のファ ン・エーステレン達の案は、1925 年の新オペラ座競技設計で 1 等に なったスタール (J.S. Staal) 案 (Fig. 5)への批判として出されたもので、 スタール案を「ムゼウム地区の動きを閉鎖する」とし、彼等の提案 (Fig.6)が「もはや暫定的なものではなくムゼウム地区の永続的な機 能を規定するもの」だと述べた ${ }^{52)}$ 。彼等の提案は「都市問題の解決 的アプローチであり、都市交通を強化する」53）と説明され、RMの 裏手中心からまっすぐ伸びた自動車道、ムゼウム通りを建設する。 道路の両脇には芝生地があり、その上に道路に対して左右対称に大 型建築物が予定されている。AMP 空間を縁取る植栽が、この場所と 周辺の古い街並とを分けている。1952 年の市の提案（Fig. 7) で変更 されたのは、RM 前の林が残され、大型文化施設の配置が非対称になっ た点である。激しい抗議行動にもかかわらず 54)、最終的にこの案の 文化施設を除き、KLM オランダ航空のバスターミナルを南東隅に加 えた案（Fig. 8）が市議会に承認された。この案の説明文は「RMか ら伸びる軸線である道路は、まさにオランダの美の殿堂を建てた建
築家の意図したことだ」という言葉で始められていた。それに対し、 市の前書記官であったデ・ブッシー（A. le Cosquino de Bussy) は「都 市開発部はこの案を正当化する為に RM の設計者を持ち出すのは間 違っている、だいたいカイペルス案（Fig. 9）とは一中略一違う物だ」

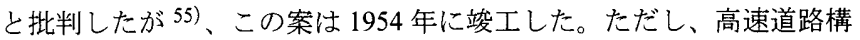
想はこの先進まず、ムゼウム通りは「最短の高速道路」というあだ 名で揶揄される56)。

\section{4-2. わき起こる交通機関建設反対運動や地域改善嘆願}

1950 年代から 70 年代は交通網や都市開発計画が盛んに行われた 57)。フールトセンは、70 年代には都心再生の動きもあり、AMP 空間 への提案も、建築物の建設による開発提案が主だったと述べている。 70 年代末からはこの周辺地域の交通開発の反対や治安向上等の地域 改善の嘆願も見られる。モータリゼーションによって AMP 空間は駐 車場と化していた。1981 年にこの地区の治安と環境改善を訴えて署 名を求める為に配られたチラシ「CG-ムゼウム地区の改善」58) 上 部には、場所の印象を表す単語として「停滞、不潔、崩壊、ドラッ グ、迷惑行為、不安全、破壊、暴力、劦し、泥棒、垣落、恐怖、虚 脱感」が羅列されている。1977年には「AMP行きスキポール線反対 」59）の嘆願書が提出された。1983 年の「これ以上の交通開発禁止！」 60)という運動は、この地区の商店組合によるもので、主にAMPを 周遊するトラムやバス路線の開発に反対する。開発により、自動車 300 台分の駐車場が失われ、商店街が駐車場と化すことを危惧してい る。1977 年と 1978 年に、都市計画に関する独立諮問機関 (ARS) が AMP とその周辺の都市開発に関する意見書 ${ }^{61)}$ を作成した。1978 年 の意見書には AMP の評価点として、文化との関係性があること、行 動や遊びには規制がないというこの場所特有の空間体験の可能性を 持つこと、都市開発と建築が関係できることの 3 点を挙げている。 過去2、30 年の急速な都市開発行為は劦威で、交通関連の建設が AMP 空間の価值を破壊したと述べる。続けて、初期の計画や建築の 配置に現れている価値を取り戻し、場所の健全を回復する為に AMP と周辺のマスタープランの必要性を訴えている。その際ニューマル クト地区のように ${ }^{62)}$ 街の顔を守るという方針で計画案を募ること、 この場所の印象と機能を「高速道路」から変更すること、車の交通 量を規制し、自転車の往来や散歩の権利を取り戻すこと、文化的機 能を強め、新たな文化政策やサービスを行う為の第 5 番目の文化施 設用に南西部の土地を確保すること、遊び・文化的表現・社会に対 する声明を発表できる場所とすること、地下駐車場の必要性と市に 早急な計画検討の開始を求めている。付録には、AMP 空間での歴史

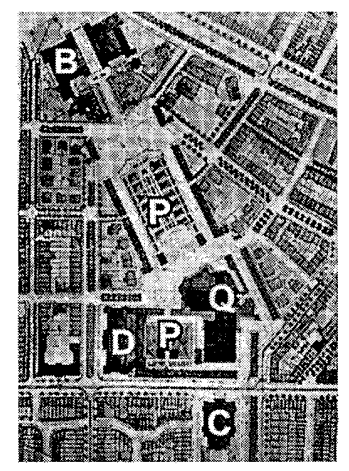

Fig. 5 J.S. Stall 1925 年 Q. オペラ座、 P.オープンスペース (庭)

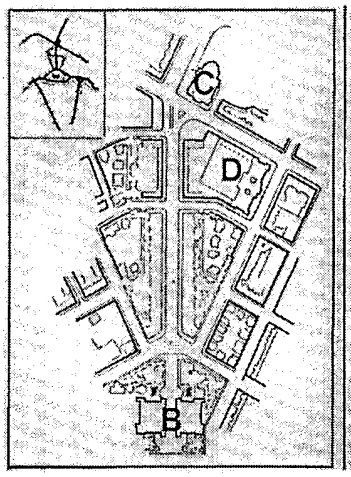

Fig. 6 J.M. De Casseres, C. van Eesteren, Ch. Karsten, B Merkelbach の連名案 1929 年

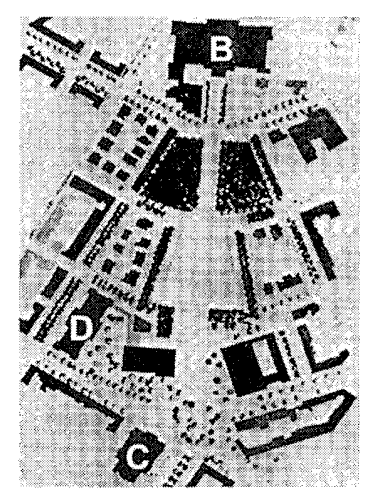

Fig. 7 都市開発部 (ファン・エー ステレン) 案 1952 年

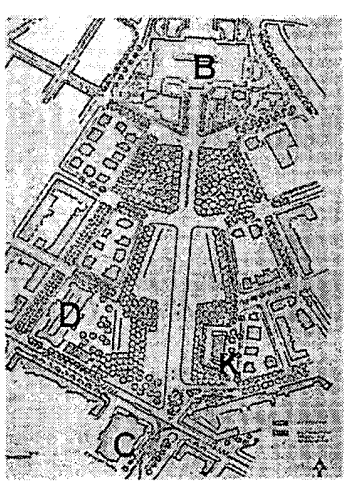

Fig. 81954 年に施エされた案 K. KLM 航空バスターミナル 
的出来事の年表と共に、祭り、スポーツ、戦争時の様子等の写真や スタールの新オペラ座計画案の模型等の写真が掲載されている。

\section{4-3． 強められる文化中心性}

19 世紀末からのこの場所の地図上の表記は、アイススケート場、 スポーツパーク、ムゼウムプレインまたは無記名と様々だったが、 1960 年代迄にムゼウムプレインに落ち着く傾问が見られる ${ }^{63)}$ 。この 頃から AMP 空間の文化的側面をより強化する計画が進行していた。 リートフェルト (G.T. Rietveld) の遺作となったファン・ゴッホ美術館 (以下 VGM) が 1974 年に開館した。この美術館はオランダが誇る近 代美術館であるばかりでなく、オランダの文化宣伝と観光の目玉と しての意味も大きい。独自に改装計画を進めていたのは CGで、建 物の老朽化々設備の陳腐化、手狭になった事務所や待合ロビー等に 対応する為の改修・改装計画の為の組織を 1983 年に設立した。19世 紀末に有志市民の活動で設立した CG は、今回は資金の約 3 割強が 市とオランダ文化財保存記念物局によってもたらされ、約 4 割が私 的団体や個人から、残りは特別行事や宝くじの収益金で集められた。 1988 年の 100 周年に合わせて、デ・ブライン (P. de Bruijn)の設計で 拡張部分が開館した ${ }^{64)}$ 。桩張部は、東道路側に既存建築物に沿わせ るように控えめに付加され、鉄の部分は本体の棟瓦色に合わせて何 色か採用され、残りはガラスで覆われる（Fig. 10)。2 階には幕間の 談話のバーがあり、建物外壁の外側を空中散歩するという建築文化 財の新たな楽しみ方も提供する。拡張部は、夜には光の箱となり、 AMP 方向とも新たな関係性を生む。更に 100 周年を記念して専属才一 ケストラは「王立」の冠を得た。

\section{4-4. 新聞紙上の議論の拡がり}

1980 年代に入るとムゼウム通りを起点にしたハーグへの高速道路 開発は断念された。1987 年 1 月に市の都市計画の助役が「構想だけ れども国立博物館の地下にトラムを通したい。しかし上物は国で土 地は市のものであり、また市民や館長の反対でなかなか難しい」と いう由を語った ${ }^{65)}$ 。この頃から AMP 空間に関する新聞報道が増え てくる 66)。同年 7 月にパロール紙は AMP 空間の 20 世紀について特

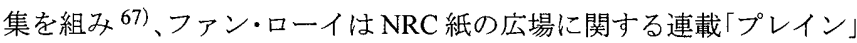
に記事を書いた。これは紙面の約半分を占める記事で、彼は1925 年 の新オペラ座競技設計や1 983 年が博覧会の為にこの場所に競技設計 が初めて開催された 100 年目であることに触れた後、「私としてはこ の場所を文化施設やカフェ等のある文化の中心にしたい。色々なも のが集まった AMS の代表的な文化中心になれば散策も楽しくなると 思う。皆さんはどう思いますか。もう一度競技設計をしましょうか。」 という問いかけで締めくくっている ${ }^{68)}$

翌年 4 月 29 日の NRC 紙の文化面に、彼は AMP への競技設計の

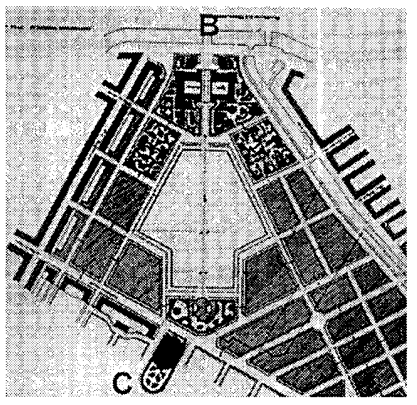

Fig. 9 カイペルス案 1891 年

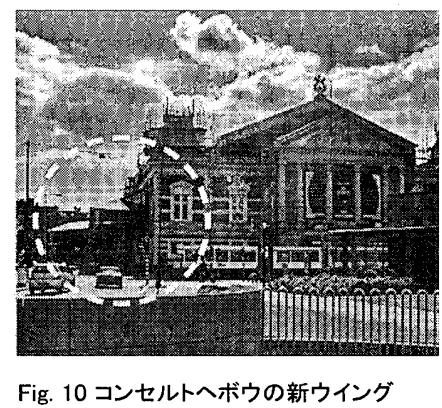

(破線内部) P de Bruijn 1988 年
告知を揭載した。同年 8 月の競技設計の締切りの延長告知 ${ }^{69)}$ には、 AMP が年間通して楽しめる場所になる理想的な計画を募集してお り、年末にはSMA で応募作の展覧会が開催されることが告げられて いる。要求項目には、「最短の高速道路」は無視してよく、最低 1500 台分の乗用車と 20 台分のトロールバスの地下駐車場の設置が必須で、 加えて SMA の入口を広場側にも設けること、木々をなるべく残すこ

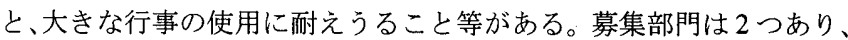
1 つは建築・都市計画の専門家や学生部門、もう 1 つがそれ以外の 部門である。さらに、「賞金より、作品の出来により本格的な競技設 計が行われる可能性があること」が重要だと書かれている。審査員 には彼に加えて建築家のヨー・クネン (Jo Coenen)、後にAMP 計画 の諮問委員にもなるフールトセン、国の社会文化計画局長のファン・ デル・スタイ (A. van der Staay)、建築・都市計画・芸術の月刊誌『アルー ヒス (Archis)』編集長のファン・ダイク（H. van Dijk) が名を連ねてい る。ファン・ローイは、彼がこの企画を始めた時には、確実な開発 計画もなかったし、競技設計後に計画が本格化する予定もなく遊び で始めたが、議論が盛り上がって、何か本格的に動き出せばと真剣 に競技設計を企画したと語っている ${ }^{70)}$ 。競技設計は盛況で、200 点 以上の応募があり、180 点以上の作品が SMA に展示された ${ }^{71) 。 こ の ~}$ 競技設計とその後について、ファン・ローイが企画・製作したドキュ メンタリーのテレビ番組によると、建築家から芸術家、各種活動家 など実に多様な人々からの提案があったことがわかる。エベリンク もこの競技設計は一種の祭りのようでもあり、オランダ中から作品 が集まり、実際的な計画提案から芸術作品としてこの場所を風刺す るものまで様々だったと述べている72)。この競技設計では、3 作の 優秀作品と 14 作の入選作が選ばれた ${ }^{73)}$ （Fig. 11，12）。それらの作品 は、方法はどうであれ AMP 空間がなるべく広いオープンスペースと なるものである。フールトセン曰く、ムゼウム通りを「最短の高速 道」の記念碑として残すという意見や、AMP 空間の中に建築物を建 てて開発する案もあったが、この競技設計で彼を含む審査員達が行っ
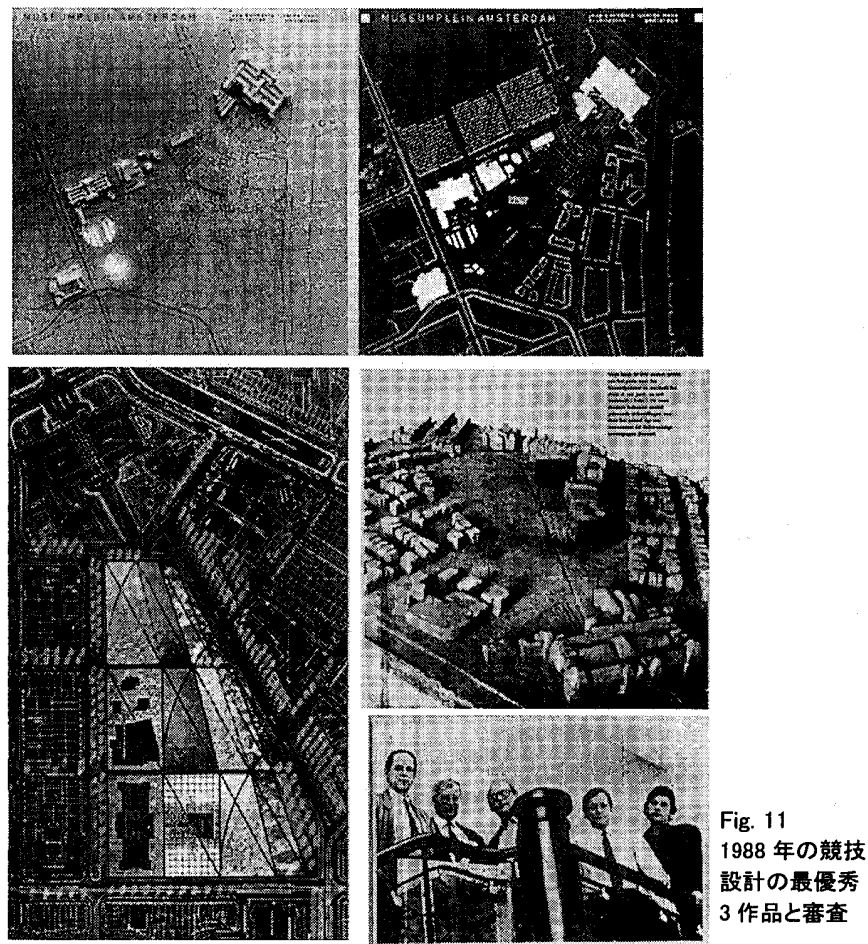
たのは、「空っぽ」であることがこの空間に必要な価值であることを 示し、象徴的に都市を分断していたムゼウム通りを解消し、アムス テルダムと AMP 空間を再び慗ぐことだった、と述べている ${ }^{74)}$

競技設計後、事態は動き始めた。翌 1989 年 4 月 1 日にハイネケン ビールの経営者のハイネケン(A.H. Heineken)が「私はアムステルダ ムに生まれ、この街を愛してる」からと、1案をパロール紙に発表し た ${ }^{75)}$ (Fig. 13)。これは1面を占める特集記事だったが、卓越した経 営者として有名な彼の提案が新聞に大々的に載ることは、この話題 をさらに盛り上げる効果があったのではないだろうか。また、この 年の年始には CG、SMA、VGM の館長らが話し合い、SMA の拡張と AMP 計画をヴェバー (C. Weeber) に依頼していた。6月にヴェバー 案を提出された市の都市計画の助役は、「まず予算を検討しないと 何とも言えない。夏以降に都市計画部と諮問機関が一緒に検討でき るだろう」と答えている ${ }^{76)}$ 。ヴェバー案 (Fig. 14) ではSMA 新館が $\mathrm{CG}$ 前のファン・バールレ通りに沿っていっぱいに拡張され、AMP は RM と SMA 拡張部の間に建築に囲まれた、閉じた広場として設け られる。広場にはVGMの拡張阡画の新棟の建設も予定され、RM と SMA 拡張部の中心軸の交差点には記念碑を設置する ${ }^{77) 。 C G ~}$ と AMP を慗ぐ若干の緑地はあるが、両者は視覚的に切り離されている。巨 大な SMA 拡張部を含むヴェバー案への批判や反対意見もあり、それ らもまた新聞に掲載された ${ }^{78)}$ 。SMA、VGM は熱心に拡張を望んで いたが、同年 10 月の市の美術に関する助役の意見は、美術館の拡張 の可能性はあるが、19 世紀美術の美術館の拡張計画として、ヴェバー

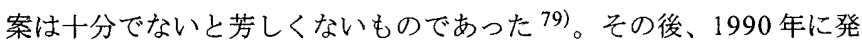
足した南区 ${ }^{80}$ ) は、最終案に媻がる「南の庭」(Tuin van Zuid) を発表 したが、パロール紙は1991年にも続けて様々な趣向を持った提案図 を掲載した記事を何度か組んでいる。

\section{5. 新ミレニアムに向けてまとめられる計画 \\ 5-1. 自治体と識者による基本計画}

新たに発足した南区が AMP を管轄内に持つことになり、この場所 の完成にむけて動きだした。1994 年発行の『コミュニケーションす るプランAMPの改修』と題された、AMP 計画の経緯、概念、予定、 予算をまとめた文書によると、1990 年 6 月にエベリンクと南区の都 市計画部は基本概念作成の為に調查・研究を始め、年末に「南の庭」 (Fig. 15) と題する案を発表した ${ }^{81)}$ 。エベリンクは、オランダ人以外 の設計者に委ねる為に、基本概念を作成する由を説明されていたと 述べている。南の庭案では、AMP の南側に建設物等はなく、広く開 放された空間が中央に取られる。南東角の木々で守られた空間にナ チスの女性収容所、ラーフェンスブリュックの追悼碑を設置する。

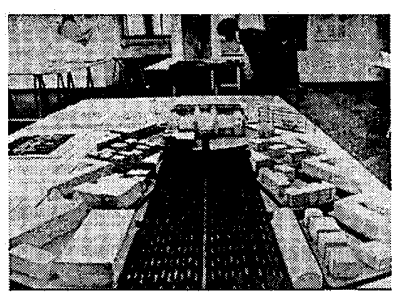

Fig. 12 「世界で最も短く、乱暴な自動 車道への誉れ高き暗示」J. Körmeling J. van IJzen 1988 年。旧ムゼウム通 りを批判的に扱つた作品。入選作で、 ユトレヒト市立博物館が買い取った。

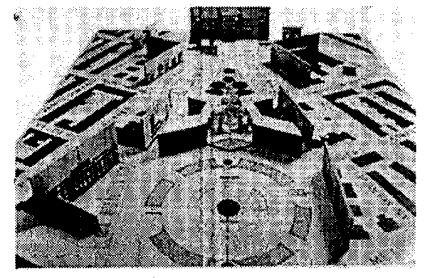

Fig. 13 A.H. Heineken 案 1989 年 AMP から撤去する彫刻や構築物、地下駐 車場と地下鉄の出入口、新たに建設する 住宅群、動く歩道、噴水広場、記念碑等 を示した。中央には SMA 新館のガラス建 築を計画している。

SMA とVGM は拡張が予定され、本館と新棟の間や、AMP の間には テラスや花畑が設けられ、その間を遊歩道が走る。1992 年に市長と 市議会はその基本概念を承認した。南区は、都市計画家のフールト セン、ARCAM 代表のクロース、ランドスケープアーキテクトのホ スパー (Alle Hosper) らに諮問委員になるように依頼し ${ }^{82)}$ 、各文化機 関の拡張計画を新しいAMPに関係させる為に、SMA とVGM を迎 えた委員会を発足させた。上記 3 名が諮問委員として選ばれたのは、 ぞんな機関にも所属しない、独立した専門家ということが重要だっ たという。またフールトセンは、当時彼が都市計画家として活動し ながら、19 世紀的都市の価值に敬意を払うべきだという内容の講演 を方々で行っていたことも依頼された理由だろうと述べている ${ }^{83)}$

\section{5-2. 最終案人}

諮問委員会はアンデルソンをAMPの設計者として指名した。彼等 はオランダ人にとって AMP 空間は思い入れの強い場所であるうえ に、AMPの議論があまりにも大きくなり、あらゆる人々が関わり過 ぎ、各人が AMPにたいして確固とした考えを持ちすぎていると考え ていた。その為、全く新しく、この議論に無関係だった人物に AMP の設計を依頼することにした。また、当時の建築家や都市開発者達 の中には、建物による建設開発を主張する意見も多く、彼等は建物 にとらわれすぎると考えた為、ランドスケープからアプローチして $\mathrm{AMP}$ と都市との関係を生み出せる人物を求めた。つまり、建築家や アーバンデザイナーではなく、外国人のランドスケープアーキテク トに設計を依頼することで合意した。侯補者の中からアンデルソン が選ばれたのは、ウイーンのカールスプラツを高く評価したことと、 パリのラ・デファンス等の首都の都市広場の計画にかかわった経験 をかったという。特にホスパーは「静寂」の質もこの場所に必要だ と考え、また北欧のランドスケープデザインの伝統を受け継ぐ者と してアンデルソンを推した。南区は AMP を実現させようという強い 意志を持っており、委員会は困難な計画を幾つかやり遂げていたガ ルにアンデルソンの補佐を依頼した ${ }^{84)}$ 。VGM は新棟の設計者に黒 川紀章を指名した。SMAの拡張にかんしては 1992 年に指名競技設計 を行いヴェンチューリ (R. Venturi)を1等とした。1993 年にはアンデ ルソンによって初回のマスタープランが発表された。

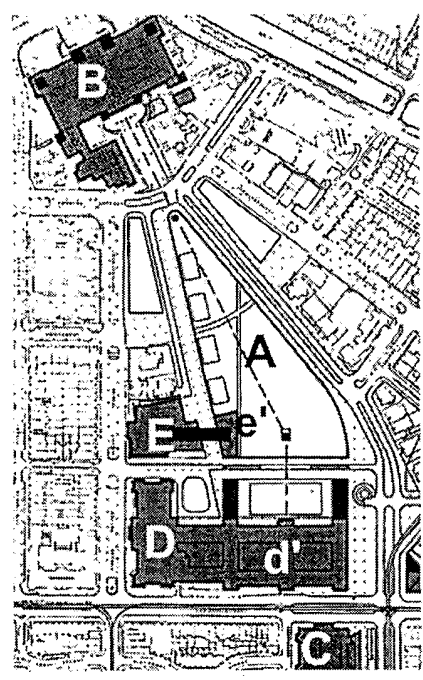

Fig. 14 C. Weeber 案 1989 年 d'.SM 拡張部分

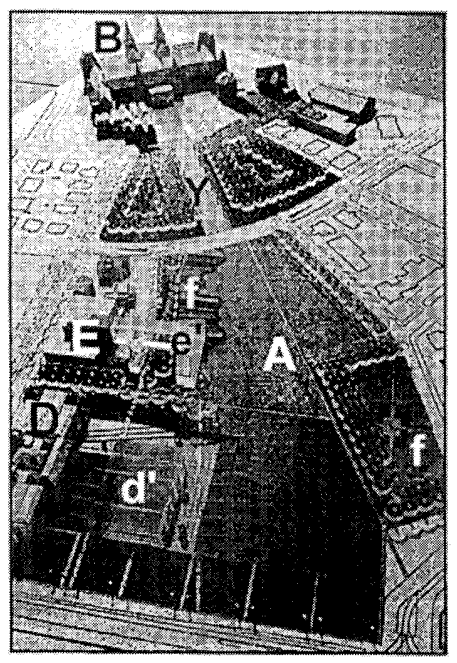

Fig. 15「南の庭 アムステルダム南自治体 1990 年 d'.SM 拡張部分、f. 花㚼 


\section{5-3. アンデルソン案の評価}

アンデルソンのマスタープラン発表と公開説明会にともない周辺 関係施設や関係団体、個人からの賛否両論の意見が寄せられた ${ }^{85) 。 ~}$ 同年にアムステルダム市の都市計画に対する独立諮問機関（ARS） もアンデルソン案に対して意見書を出している ${ }^{86)}$ 。10 の意見があ り、多少解決すべき問題を示しているがおおむね賛成意見である。 第 1 番目は、ARS はこの計画に満足している。落ち着いてしかも寂 しい場所でない。また地域全体の景観を整えている。広い空地があ り、大きな行事の使用に耐えうる。この案は良い中立性を持っている。 池と木々の列が空間の調和を醸し出し、AMP と CG 周辺空間との関 係を創りだしたことに対して満足している、と述べている。第 2 番 目に解決できていない難解な問題として「夕方には暗く無人となり 安全でない。大勢の人がこの場所に来る動機があるべきだが、多く の機能（店舗や飲食店等）を加えると場所の中立性が失われる。」 ある。第 6 番目には、今後の美術館の改装はこのマスタープランを 考慮するべきで、アンデルソン案がこの空間を規定する最も重要な 指針とされることを求めている。ARS は AMP が周辺の多種の要素を 調整しながら調和させる機能を獲得したことと場の沉用性が保たれ たこと、また空間の中立性に高い価值を置き、それらを高く評価した。 5ー4. ムゼウムプレインヘ

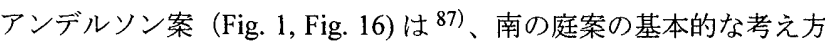
を踏襲している。まず中心になるべく広くとぎれることのない空間 を再獲得させた。AMP 側と各文化施設の間に関係をつくり、さらに 文化施設同士も関係を持つように美術館の拡張範囲を設定し、遊歩 道を配す。また、AMP と周辺市街地を分割していた木立の縁取りの 一部を撤去し、AMP を周辺都市とより直接的に熬げた。RM の手前 の扇状の「美術館の小さな森」も以前の記憶を残すように木立を間 引いた。おかげで、RM 中央を貫通するトンネル状の歩道と自転車道 を旧市街地側から抜けると、南へと拡がるアムステルダムを、より 広々と体感することができる。美術館の小さな森中央の池は夏はプー ル、冬はスケート場となり、その他バスケットコートやスケートボー ド場等もある。小売や喫茶のパビリオンもここに設けられる。AMP の北側に集中して活動的な要素を配置し、南側を広い開放空間とす る。賑わいを持ち込むと同時に、既存の季節的、仮設的で不特定な 使用の可能性を最大限に残した。AMP 空間の最大の変化は、CG 東 側のデ・レレッセ通りの北端、つまり AMP の南端から RM の西脇に 向かう光のラインによってもたらされた。光のラインは遊歩道であ り、夜は埋込み照明が地上に光の線を描き、地下駐車場に光を与える。 旧ムゼウム通りはこの位置から RMの中心に向かっていたが、光の ラインは何の目標物もない北西の空閒へと向かう。この 3 本目の大 きな軸性は、AMP 上に絶対的で、記念碑的な軸性の可能性を打ち消 寸為に設けられたという。RMからの軸線はそれをなぞる形で池を設 置することで止め、また建築物や道路などの AMP を取り囲む都市的 な要素からの軸線も延長して AMP 内に導入すると共に、その強さを 平均化する ${ }^{88)}$ 。さらに、他の文化施設を通って RM と CG を結ぶ末 広がりな遊歩道と、SMA と VGM の間には人溜まりのできる空間を 設け、そこから東へ拡散する 3 本の小道を設定した。遊歩道のスト ライプの床パターンは、南側道路の人波や交通の不規則なリズムを AMPに引き込む為に設汁たという。また、王立オランダ自動車協会、 アメリカ領事館、学校等の重要な施設も立ち並ぶ東側では、木立や
花畑によって周辺の都市要素が段階的な干渉を経て AMP と関係する 構造を作り、文化施設のある西側は、抽象的な形の抽象的な配置に よって「何でもなく、何にでもなれる」空間としたという。この抽 象的な、というのは、VGM の新館と、SMAの隣にある、あたかも 本のページの角が折られてめくれ上がったように地面を持ちあげた、 ドンキーイヤーとも呼ばれる 3 角形の芝生斜面の形と配㯰のことで ある ${ }^{89)}$ 。ドンキーイヤーは、地面を連続的に空へと上昇させること で、AMPにさらなる空間の拡がりを与えるために設けられたという。 この場所は、人々が日光浴をしたり、子供たちが駆け登ったりと利 用頻度は高い。南東のトラム線路との緩衝地帯の花畑の側には、ラー フェンスブリュックの追悼碑の彫刻が改修されて再設置された。

アンデルソン案への批判や抵抗、計画推進の困難はもちろんあっ た。ガルによると、特に東西を結ぶ小道に関しては、アンデルソン はデンマークのやり方として、予算の一部を取り置き、竣工後に人 の動きを見てから設置したいと主張したが、オランダではそのよう な予算の配分は無理だった。そのため、アンデルソンは予測的に 3 本の小道を設置しなくてはならなかった。他の文化施設の拡張計画 との折衝の困難もあった。VGMの新棟を担当していた黒川紀章は、 最初は AMP のより中央近くに、大きな円筒形の建築物を建てる案を 出していたが、アンデルソンは黒川案の規模を縮小し、建物の位置 を本館側に寄せ、形を棈円形にするように説得することに成功した。 SMA に関しては、最初の設計者ヴェンチューリとは、ファン・バー ルレ通り側に入りロを設け、そのアトリウムの空間性をVGM 側まて

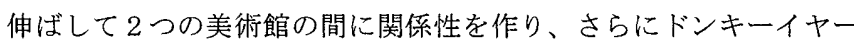
との間にも何らかの関係を作ることで、街路側、文化施設間、AMP 側のどの方向も人通りのある生きた空間とすることを確認し合って いたという 90)。最初ヴェンチューリは、ドンキーイヤーとの間の空 間を裏庭と呼んだが、「何でもなく、何にでもなれる」場所にするこ とにも合意していた。しかし、ヴェンチューリの計画が中止になり、 当時の SMA 館長フクス (R. Fuchs) は、今度はシザ (A. Siza)を設計 者として指名した ${ }^{91)}$ 。フクスはアンデルソンの AMP 計画に対して はあまり肯定的でなく、また SMAにとって有利な案でないと考え ていたためか 92)、シザ案は AMP の基本概念を考慮しない設計だっ

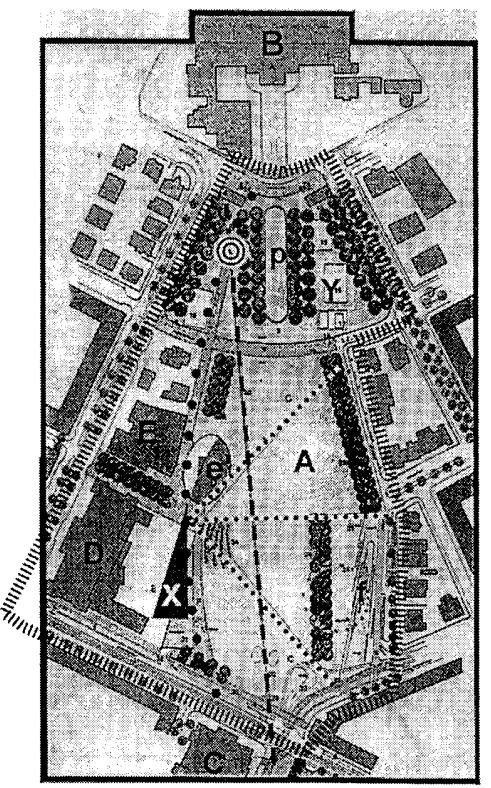
Fig. 16 アンダーソン案 1993 年 ( 及び Fig. 1 参照) 国立博物館側（上）が北。 A. ムゼウムプレイン (AMP) B. 国立博物館 (RM) C. コンセルトヘボウ (CG) D. ステイデリック・ムゼウム（SMA） E. ファン・ゴッホ美術館 (VGM) $\mathrm{e}^{\prime}$. ファン・ゴッホ美術館 (VGM) 新棟 X.ドンキーイヤー Y. 美術館の小さな森 （国立博物館前の扇状地） ○噴水 - - - - - 光のライン ......楕円弧状の小道 ............... 東西を結ぶ3本 p. 池 のライン

f. 花畑 アンダーソン案の マスタープランの 計画範囲 
た。シザはアンデルソンの薦めと南区の承認によって、地下駐車場 の入口の意匠設計も任されており、アンデルソンは最終的にドンキー イヤーの下に地下駐車場とスーパーマーケットの入口を設けること を妥協していた。しかし、その直後にシザはドンキーイヤー自体の 撤廃を要求した ${ }^{93)}$ 。アンデルソンはドンキーイヤーを AMPにとっ て重要な要素と考えていたが、シザはかなり強固に自分の意見を通 そうとした。ただ、ガルとアンデルソンはシザの駐車場の入口案が、 初期予算をかなり上回るうえ、シザの SMA 拡張計画も実現するかは 考えにくい案だと思っていたという。その為、今後どのような建築 家が SMA の増筑を担当することになっても、マスタープランに配慮 して設計を行うことを気づかせる暗示として、この位置にドンキー イヤーを設置する必要性を再認識したという94)。

開園日、1999 年 8 月 22 日のプレイベントは、正午のピクニックに 始まりスポーツ、野外レストラン、出し物や工作教室などが行われた。

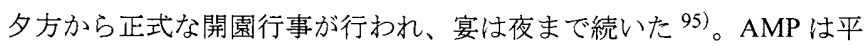
常時は、近隣住民や観光客の昼食、日光浴、散歩、通り道に使われ、 観光の中心地でもある。また、AMP は 10 万人以上が集まることも ある有数のデモ会場であり、女王の日やホラントフェスティバル、 フットボールのヨーロピアンチャンピオンや地元クラブチームの優 勝時の集会等の国家、国民、国際的行事に使用される。

AMP は、各文化施設背後の都市計画が定まらない裏側的存在から 脱却し、中心性も獲得した。この中心性は強い求心性を持つもので なく、ここに慗がる建築、道路、人の流れといった都市の要素を引 き込み、 $\mathrm{AMP}$ 上で緩く交差させながら、再び市内へと解放する環境 を設定しょうとしている。強力な軸性や特定の文化施設を景観上の 頂点とすることや中心性を作り出す焦点となる場所の設置、形式を 高める為の空間の対称性や幾何学的な完成形は避けられている。ま た、アンデルソンは AMP を公園であり広場であり、考え1つでどん なものにもなれる開かれた空間と言ったが、場の汎用性を保ちなが ら、賑わいと静寂の両面が求められた ${ }^{96)}$ 。

\section{6.まとめ}

AMP 空間は 20 世紀後期には VGM や CG オーケストラの「王立の 冠」の獲得など、国家・文化的な性格を強めながらも、20世紀前半 に成長した国民的性格も保った。様々な提案と試行錯誤の歴史の後 に都市の多様な要素を受け入れる素地をつくり、AMP として正式に 開かれたことで、首都における文化中心地としてより確実な存在と なった。また、19 世紀末に必要が訴えられた都市広場としての価值 も獲得し、文化施設の裹側的存在を脱却し、中心性を確保しながらも、 支配的な軸性を否定し、形式を打ち消すような操作が行われた。こ の点で AMP は階層をこえた文化横断的な日常的な祝祭空間である。

20 世紀末の AMP のランドスケープデザインは、20世紀後半の芸 術や社会の動きを反映している。SI は前衛芸術を「大衆から活動性 や創造性を奪うもの」として批判した。全てのものから解放された 人間主体の理想都市を構想したコンスタントの「新バビロン」は、 60 年代に社会的流行となり、当時台頭していた新左派社会主義者に も影響を与えた。その主張の 1 つは「文化の平等な取り扱い」によ る生活の質の向上であった。60年代の社会変革を通して、この場所 の議論が再燃した 20 世紀後半には、エリート・ブルショア層の 19 世紀的市民に加え、大衆も都市計画や都市の文化を象徵する空間の
デザイン決定に関与しはじめ、無視できない存在になった。70 年代 には、AMP への都市開発反対運動や地域の健全化を求める運動が起 き、ARS は「自転車の往来と散歩の復権」と文化施設の追加や自由 に文化的な表現や発言が行えるという「文化的機能」の強化を求めた。 80 年代には、都市計画の発展はエリートに支えられながらも、その 計画と合意形成の過程に透明性を追求した水平協議の時代に移行す る。また「柱」を離れた新聞が 80 年代に、都市の文化中心地として AMP 改装の議論の口火を切り、盛り上げたことも象徴的だ。ファン・ ローイが真剣な遊びとして始めた 1988 年の競技設計は、この場所の 重要性と人気を再確認寸る出来事だった。また、この審査員達は「空っ ぽ」であり開放されていることが AMP に必要な価值で、象徴的に都 市を分断していたムゼウム通りを解消し、アムステルダムと AMP 空 間を再び繋ぐべきだと示した。1990 年の南区の発足は、AMP の実現 を強力に後押しする転機となった。また、NRC 紙の競技設計とその 後の新聞紙等で繰り広げられた報道や批判、提案も、最終案の基本 計画をまとめる為の取捨選択要素を抽出し、この空間の価值や意味 の確認と、それを AMP のランドスケープデザインに反映させる為の 重要な過程だったと考えられる。エベリンクと南区は研究の上に基 本案を作成し、独立した個人の専門家に AMP 計画の諮問委員を依頼 したが、委員の一人は、1888 年の競技設計の審查員でもあったフー ルトセンである。諮問委員会は、今までの AMP 議論に無関係な全く 新しい人物で、なおかつ建築に囚われすぎずにランドスケープの視 点から都市空間に関われるものとして、外国人のランドスケープアー キテクトを AMP の設計者に指名した。アンデルソンはなるべく広い オープンスペースの獲得と AMP の空間的桩がりを重視した。ARS は アンデルソン案が周辺の多様な要素を調整しながら調和させたこと、 場の汎用性が保たれたこと、また空間の中立性に高い価値を置いた ことも評価した。この場所に慗がる周辺都市からの要素はAMP 空間 に導入されるが、方向付けられることはなく、再びアムステルダム 市内一と返される。また、日常・非日常、組織・非組織の種類を限 定しない活動が AMP で行われることで、活動内容の固定化をさけ、 自由な表現の可能性と機会を生み出すための仲介役としての役割を AMP のランドスケープデザインが担わされている。

本稿では 20 世紀後期の AMP 空間の議論の動向に注目した。今後、 AMP に提案された計画案の構成要素や計画動向の時系列的な変化を 建築や芸術社会運動と共に比較分析するととともに、近現代の建築 運動や都市化、造園分野の相互関係の中で、60 年代を経てオランダ の近現代の都市のランドスケープデザインがどのように発展してき たかの研究にも発展させたい。

謝辞 インタビューを行った、M. van Rooy、 R. Geurtsen、M. Kloos、S.Gall、H. Ebberink の各氏には資料収集や情報提供等のご協力、ご教示を頂いた。J.C. Kennedyアムステルダム自由大学教授にはオランダで出版された氏の博士論文 を頂戴した。また、留学中の奨学金を頂いた国際ロータリー財団や Leiderdorpロー 㚈ークラブの B.J. Lietaert Peerbolte 氏、Nel とJan Slagter 夫妻、ライデン大学で の指導教官 A.J.J. Mekking 教授、日本語学科の国森正文先生と夫人の由美子様 にはオランダ語やオランダに関する知識等、様々なことに協力頂いた。この研究の 一部は財団法人日本科学協会、笹川科学研究助成を受けて行っている。末筆な がらここに深い謝意を表します。

注 *本文にて既出でない人名、地名については原語表記とする。

1) 前回の拙者の論文、田村望、「アムステルダム、ミュージアム・プレインに見るオラン ダ 19 世紀後期ヨーロッパ近代首都としてのランドスケープ形成汇関する考察」、日本 建築学会計画采論文集 第 607 号、2006 年 9 月、pp.215-223.から幾つかのカタカナ 表記を改めた。ミシージアム・プレインームゼウムプレイン (AMP)、シンセルト・へボー ↔コンセルトへボウ (CG)、ステデリック・ミュージアムーステイデリック・ムゼウム(SMA)。 2) Amsterdam city, Choosing Amsterdam, Brand, concept and organization of the city market- 
ing, 2003 に 'the potential contact point’ $の$ 上位としてあげられている

3) 建築史分野と比べ後発であるが、アムステルダム自由大学、ライデン大学、デルフト 工科大学等でも近現代ランドスケープデザイン史の研究が進められてきている。AMP はこのような書籍の中で紹介される一例でもある。オランダの庭とランドスケープデザ インの図面や写真入解説辞典、C.S.OLDENBURGER-EBBERS, A.M. Backer \& E Block, Gids Voor de Nederlands Tuin- en Landschapsarchitectuur, De Hef Publishers Rotterdam, 1998 や 20 世紀オランダの庭とランドスケープデザインを写真等と共に紹介、解 説した、G. Deunk, 20th Century Garden and Landscape Architecture in the Netherlands, NAi Publishers, 2002 等が出版されている。

4) 田村望、 op.cit., pp. 215-223

5) 本論文で「大衆」とは、19世紀後期から徐々に指導者䈏、裕福層といわれる既存 市民の中で参政権を持ったものに加え、参政権を持たなかった裕福層、労働者階級、 女性等にも参政権が認められ、これらの人々を含んで拡大した市民を「大衆」と呼ぶ。 また、19 世紀におけり市民で参政権があったのは一定納税額以上を収めるものであっ た。19世紀後期から市民䅔が拡大しはじめ、20世紀に入ると労働者階級も市民と認 められるようになる。19 世紀末から20世紀にかけてのオランダ社会は「柱状化」とい う言葉で表現されることが多い。様々な政党が成立し始め、社会はそれぞれの「柱 を指導するエリート達の政治によって互いの柱を侵さない上うに平和的に共存してきたと いわれる。また労働者階級も政治に影響力を及ぼす、指導・組織された「大睡」と して重要になる。例えば、オランダの約 35\%を占めていた労働者はカソリックで、彼等 の支持を得ることでキリスト教系の政党は勢力を伸ばした。新たな市民である彼らを含 む「大衆」が、社会・政治・文化において無視できない存在となり、そのような動きの 中で様々な近代的な大衆政党が成立寸る。オランダの 25 歳以上の男性全員に普通 参政権が認められたのは1917 年、女性は 1919 年。選挙権の行使が義務制から任意 制に移行したのは 1970 年で、義務制の時代の投票率は $90 \%$ 程度だった。選举権年 路令は 1972 年に 18 歳に引き下がり現在に至る。1960 年代から杜柱状化社会が急速に 崩壃しはじめ、組織も個人も「柱」を離れた存在となってくる。「大衆」も、自律した 自由な思考と意思を持つ個人の集合である「大衆」へと変化寸る。柱状化社会やる の崩壊については本論文第 2 章でふれる。注 26) 参照。また注 27),28)に揭載した文 献も参照。オランダの選挙制度の概要は、監修内貴滋、執筆 田代ひとみ、桐野義 之、『オランダの地方自治』、財団法人日本自治体国際化協会、2005索照した。

6) Hans Ebberink \& Birgitte de Maar, Museumplein 1866-1988 De museumterreinen te Amsterdam. Een inventarisatie van de plannen, Dienst Ruimtelijke Grdening Amsterdam \& Econ. Ontw, 1988.これは、第4章で取り扱う 1988 年の AMP の競技設計の展覧会時に AMPの歴史部門の展示として計画していたものだが、応募作品の展示が多数となり、 展示スペースが不足しため、この部門の展示を中止し、代わりにこの冊子を出版したむ のである。

7) Ada Gravina, 'Van Museumterrein tot Museumplein', SIMULACRUM Nr.3, 1998, pp.8-12.

8) Lydia Lansink, 'Het Museumplein Amsterdam. Een historisch overzicht', jongHolland num mer 2, 1999, pp. $6-29$.

9) SMA PARCAM 資料室ではAMPに関する新聞や雑誌の記事を年毎に収集している。 AMPを取り上げる回数が多いのは全国紙のフォルクスクラント紙、トラウ紙、NRC 紙と 1977 年に全国紙からアムステルダム地方紙となったパロール紙である。特にパロール 紙は詳細かつ掲載回数が多い。4 紙ともに報道記事の他、場所の歷史、歴代の提案、 新たな提案、批判等の特集記事を幾度も組んでいる。また、文化面にお计書き方は、 読者に疑問を投げかけ、挑発的な表現をするものもある。その他の新聞で記事が見ら れるもので、代表的なものは、アルヘネン・ダグブラット、テレグラフ、アムステルダム スタッドブラット、エコー等がある。

10) ファン・ローイは元 NRC 紙の建築や都市計画、文化を主に執筆する記者であり その他の新聞への寄稿や多くの現代建築に関する著書むある記者。様々な大学で講 演を行い、建築設計競技の番查員なども勤める。ベルラーへは祖父。エベリンクはア ムステルダム在住のランドスケープアーキテクトで、注 6)の冊子の作成者でもある。フー ルトセンは国内外の都市計画を行うと共に、デルフト工科大学で教授を務めた。経歴も ある。クロースは建築教育を受け、非営利財闷 ARCAM を創立した。ガルはロッテル ダムにある Atelier Quadrat に所属する都市計画家。この論文に関する聞き取り調查は 2006 年に行った。エベリンク: 3 月 6 日、クロース:9月 26 日、ファン・ローイ: 9 月 27 日、フールトセン: 9 月 29 日、ガル: 10 月 6 日。

11) CG はオランダで最も権威ある、国際的評価も高い音楽ホール SMA は直訳すると 市立美術館だが、それ以上の存在で、その設立や運営は民間団体や個人の多大な 援助なくてはありえず、1945-63 年に館長だった Willem Sandbergによって、現代の現 代美術の展示・運営概念を確立した先駆的な美術館として国際的に知られる。

12) Michiel Wagenaar,'Between Civic Pride and Mass Society', Amsterdam Human Capital, ed.by Sako Musterd, Willem Salet, Amsterdam university press, 2003, p. 59.

13) 19 世紀後期の AMP 空間の起源とこの場所への提案については前回の拙者の論文 で論じた。田村望、op.cit., pp. 217-220.

14) 田村望、op.cit., pp. 216-219.

15) Ibid., pp. 217-220.

16) Hans Ebberink, Birgitte de Maar, op.cit., p. 36 .

17) Lydia Lansink, op.cit., pp. 14-15. また、この周辺の建設が進むのはAMPの側に建つ ていた蛹燭工場が、1891 年に 1901 年の移転を決めたことも理由の1つと考えられる。

18)アムステルダム市アーカイブは 1885 年頃からの AMP 空間でのスケートや運動会、 出来事、祝祭時の写真考所蔵している。

19) 1917 年に労働者達が国内の食糧難に抗議してジャガイモ騒動が起こった。

20) Holman Theodor, Photography Siebe Swart, 'Museumplein', Museumplein, Nai Uitgevers, 2000, p. 5-6. 及び. アムステルダム市アーカイブ所藏の写真資料による。

21) Hans Ebberink, op.cit., p. 48

22) ファン・ローイ、フールトセン、クロースによると、1950 年代加 1988 年の競技設計 までにもかなりの数の提案が、建築や美術系の雑誌、新聞、同人誌などに発表され ていたといら。

23) 50 年代末まで外国人は総じて、オランダを前時代の伝統と慣習に浸った、古風で「時 代遅れ」の社会だと見なしていた。ア归力人社会学者のロナルド・イングルハートは 60 年代初頭のライデンにいた頃を振り返って、オランダが合衆国にくらべて「非常に伝統 的」だったと述べた。ハインリッヒ・ハイネがロにしたとされる格言（時にボルテールの 作と見なされることもある）に「世界の終末がやってきたら、私はオランダに行くことに しよう。あそこは何でも 50 年遅れだから」といら台詞があって、当時ひ上うきん者が好 んで引用した。仮に「近代的」社会が、工業化社会や世俗化社会（公的な場にお
ける宗教の影響が小さい社会）を意味するのだとすれば、こうしたオランダ観は当を得 たものであったといえよう。オランダ経済は、ドイツやベルギーといった周辺地域に比へ て工業化が遅れた。歴史家たちが 1890 年代に経済的「離陸」を見いだしたりいって も、工業生産の增加は、1945 年以後まで見られない。50 年代までオランダは比較的 貧しい国であった。ストライキはまれで、外で働く女性はほとんどおらず、60 年代半ば まで賃金は比較的低かった。大規模かつ強力なカトリックやプロテスタントの下位文化 に支えられて、教会の出席者数や出生率はいずれも高く、オランダは統計学上、北 ヨーロッパで特異な存在となっていた。 J.C. Kennedy, Building New BABYLON: Cultural Change in the Netherlands During the 1960s, 1995 年アイオワ大学博士論文 p.4-5。第1 章和訳、大西吉之。(この論文はオランダで J.C. Kennedy, Nieuw Babylon in Aanbouw Nederlandin de Jaren Zestig, Boom Publishing, 1995. として出版されている。)

24）社会の「柱状化」に関しては、歴史、政治、社会学を中心に様々な書籍で論じら れている。概略を述べると、19 世紀後期からら様々な政党が成立しはじめ、それらはあ る信念に基づいたグループ（柱）を形成する。各柱は、新聞社、放送局、学校、労 働組合、病院、スポーツクラブ等の組織を内包し、ある柱に生まれた人は死ぬまで柱 による組織された社会で生活することができた。栗原福也、『世界現代史 21 ベネルク 現代史』、山川出版社、1982、p. 18 では「ある製鉄会社に㗢く労働者は垂直的に はそれぞれのグループ（柱）の労働組合の下部組織に属し、それらの下部組織は横 断的な産業別鉄鋼労働連盟に加入して使用者連盟と賃金協約を結ぶといらことになる 」と述べられる。J.C.Kennedy, op.cit., p. 9では「巨大な自由主義勢力（主流）から身 を守るため、それぞれの下位文化を維持しようとした。その結果、自由主義が望んだ 上うな統一的「国民」文化の代わりに、互いに性格の異なる複数の下位文化が生まれた。 一中略一これらの「柱」は自前の組織を過剩なまでに抱えこすようになっていた き リスト教的社会思想によって鼓舞され、各団体の相対的な自主性を認めるひとつのシ ステムがあり、すべてがそこに統合されていたのである。」と説明する。また注 5)、注 27),28)の文献む参昭

25) ed. J.C.H. Blom \& E. Lamberts, History of Low Countries, Berghahn Books, 1999, p. 438. 26) 水島治郎、『戦後オランダの政治構造 ネオコーポラティズムと所得政策』、東京大学 出版会、p. 81 .

27) Ibid., p. 84.

28) lbid., pp. 87-92.

29) Ibid., pp. 242-243. フォルクスクラント、トラウ、NRC、パロール等の各紙は元々「柱 に属した新聞だったが現在では各柱を離れている。

30) 自治体への土地買い上げ権と収用権を付与し、低賃貸住宅を投機市場から一掃す る為に自治体や非営利の住宅協同組合を対象にした長期低利融資を可能にし、人口 1 万人以上もしくは過去 5 年に $20 \%$ 以上の人口増加を見た自治体は都市扩張計画の 策定と 10 年ごとの見直しを義務づけられた。ドナルド 1. グリンバーグ著 矢代真己訳、『才 ランダの都市と集住』、住まいの図書館出版局、1999、pp. 64-70.

31）山口廣、「アムステルダム建築史」、SD 第 185 号、鹿島出版会、1980 年 5 月、p. 27.

32) Eric Munford, The CIAM Discourse on Urbanism 1928-1960, MIT Press, 2000, p. 18 33) Ibid., p. 276

34) ed.Allard Jolles, Erik Klusman \& Ben Teunissen, Planning Amsterdam: Scenarios for Urban Development 1928-2003, Nai Uitgevers Pub, 2004, pp. 52-53.

35）角橋徽也、塩崎賢明、「20世紀アムステルダムの計画綱領と政調管理に関寸る研 究」、日本建築学会計画系論文集 第 555 号、2002 年 5 月、pp. 233-235.

36) コンスタントは姓でなく、名で呼ばれることを好み、一般に名で表記されるため、本 論文でも做う。「新バビロン」は1940-50 年代に構想され製作され始めた。写真作品 は全体を俯瞰するものは少なく、内部に入り込み多様で異質なもが関係する空間の連 続を強調する。コンスタントの新バビロンやSIの都市に関しては、Simon Sadler, The Situationist City, The MIT Press, 2000 や Mark Wigley, Constant's New Babylon- The Hyper Architecture Desire, 010 Publishers, 1998. に詳しい。

37) Mark Wigley, op.cit., p. 12.

38) Simon Sadler, op.cit., p. 182.

39) J.C.Kennedy, op.cit., p. 1.

40)『ホモ・ルーデンス』はJ.Huizingaの「遊び」の理諭化に関する著作で、1938 年 に出版された。J.C.Kennedy, op.cit., p.2の注 3)等から考えると、コンスタントのいう「ホモ. ルーデンス」とは 1950 年代にフランスで文化進化論的に発展した遊び理論に触発さ れたものである。南後由和、「コンスタントのニューバビロンと 1960 年代の建筑界との 相互関係」日本建築学会大会講演梗概集 (北海道)、2004 年8 月、p. 591 は、コン スタントの思想背景には Guy Debord の批判的社会理論や Henri Lefebvreの『日常生 活批判』『都市への権利』影響がある、と指摘している。

41) 新バビロンには「宗教も、道德も、法も、芸術も、家族もなく、また都市も、住まいも、

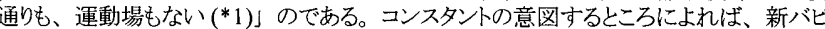

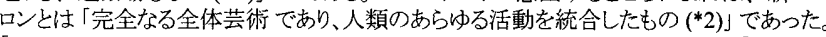
$\left\lceil\left({ }^{*} 1\right) 」\right.$ は.L.Locher, New Babylon, Gemeentemuseum den Haag, 1974, p. 12.「(*2)」は Constant, Randstad 2, 1962, p. 134.の引用。J.C.Kennedy, op.cit., pp. 2-3 で英訳されたも のを使用。

42) Simon Sadler, op.cit., p. 133

43) Ibid., pp. 152-155.

44) Ibid.,p. 155.「新バビロンは新たな経済観念における社会を前提にしており、今すぐ の現実は不可能だと気がついている。と述べている。

45) J.C.Kennedy, op.cit., p. 3

46) Ibid., p. 383

47) Ibid., p. 3

48) Hans van Dijk, Twentieth Century Architecture in The Netherlands, 1990, 010 publisher, 1990 , p. 163

49) 笠真希、「オブンダにおける都市開発のプロジェタトのプロセスデザイン」、日本建築 学会計画系論文集 第 581 号、2004 年 7 月、pp.99-97.

50) 笠真希、「オランダの協議型都市計画におらうる戦略としての都市デザインについて」、

日本建築学会計画系論文集 第 599 号、2006 年 1 月、pp. 110.

51) Hans Ebberink, op.cit., p. 48.

52) Ibid., p. 50

53) Ibid., p. 52

54) Holman Theodor, op.cit., pp. 13-14.

55) Ibid. 
56)「最短の高速道路」の他、Arend Evenhuis, Plein gezocht en niet gevonden, Trouw, 3-11-1988、にAMPに来る目的として「夢破れた大通り (Boulevard of Broken Dreams)」の上映を近隣に見いだしに来る」とある。同名のロードムービーが AMP で 上映されており、その名をもじってこの地区の事を言い表している。

57) ed. Allard Jolles, Erik Klusman \& Ben Teunissen, op.cit., pp. 124-125. 1968 年には D.A.Jokinen（ア归カ）による「都市にチやンスを！」というアムステルダムの都市交 通問題解決案が出され、高架の高速道路や地下鉄、またその周辺に多くの大建築物 が建てられる。また、地下鉄や交通開発の是非の議論が激しく行われていたと述べら れている。

58) Werkgroep "Behoud Concertgebouw- Museumbuurt", Werkgroep Behoud Concertgebouw - Museumbuurt, 1981.アムステルダム市アーカイブ所蔵

59）地区委員長の Mvan Dijk-Lely 氏と運動推進部長の J.F.H. van Rappard 氏の署名で、 "Geen Schipolelijn naar het Museumplein!”といら、スキポール空港行き鉄道線計画廃止 嘆願書が出ている。アムステルダム市アーカイブ所蔵。

60) Het sekretariaat Winkeliersvereniging Museumkwartier, BAN HET NERKEERSPLAN MUSEMKWARTIER!, 1983.アムステルダム市アーカイブ所蔵。

61) Advies van de Amsterdamse Raad voor de Stedebouw (ARS), Aan het Gemeentebestuur over stedebouwkundige maatregelen betreffende het Museumplein, 1978, より技粋。 ムステルダム市アーカイブ所蔵。ARS は都市計画に関する独立した諮問機関で、都 市開発や計画案に対して意見や助言を行い、意見書を作成し公開する。委員は経済、 商業、文化、交通、都市、建築など様々な有力者で構成される。この諮問機関はそ れほど強い強制力はないが、ある都市計画の是非について議論を起こすこともある。 後に Amsterdamde Raad voor de Stadsontwikkeling に改称。

62）地下鉄と高速道路の建設によるニューマルクト地区の住宅の取り壊しが、住民運動 により最小限に抑えられる形に変更され、1972 年には高架の高速道路建設の中止が 決断された。 ed. Allard Joli乞s, Erik Klusman, Ben Teunissen, op.cit., pp. 124-125.

63）場所の表記の確認は、アムステルダムの地図や計画地図をあつめた書籍、Marc Hameleers, Kaarten van Amsterdam 1866-2000, Gemeentearchief Amsterdam, 2002を参照

64) Hemriette Posthuma de Boer, Concertgebouw and Royal Concertgebouw Orchestra Amsterdam, Ludion, 2003, p. 27.

65) Max Pam, Een tram onder het Rijksmuseum door,Vrij Nederland, 24-1-1987.

66) SMA やARCAM はAMP 改装計画に関する雑誌記事方収集しているが、これに関 する記事は 1987 年ごろから見られはじめる。新聞ではフォルクスクラント紙、トラウ紙、 $\mathrm{NRC}$ 紙、パロール紙の 4 紙 (以下 4 紙) に多く見られる。これらの 4 紙は AMP 特 集を何度も組んでいる。年にもよるが、前記 4 紙中最も掲載回数が多いのはパロール 紙で約 3 4.5 割、ついでNRC 紙が 2 4 割を占め、フォルクスクラント紙、トラウ紙は ほぼ同程度の頻度で掲載されている。他紙では注 9)に举げたもの等に揭载されてい る。参考にSM 図書室所蔵の AMP 改装計画に関寸る1999 年迄の新聞記事の回数 を集計してみる。[/]内の数字は前が 4 紙、後ろが他紙の合計。1987 年 [4/3]、1988 年 $[17 / 2] 、 1989$ 年 $[45 / 5] 、 1990$ 年 [11/2]、1991 年 [25/1]、1992 年 [23/3]、1993 年 [36/14]、1994 年 [36/7]、1995 年 [42/8]、1996 年 [31/9]、1997 年 [33/16]、1998 年 [22/10]、 1999 年 [44/25]。

67) De Kortste snelweg van West-Europa Het PAROOL, 4-7-1987

68) Max van Rooy, Op, ten strijde tegen een onherbergzame vlakte!, NRC-Handelsblad, 29-7-1987.

69) Max van Rooy, Verlenging inzendtermijn Museumplein-prijsvraag, NRC-Handelsblad 19-8-1988.

71) ファン・ローイは AMP 空間がオランダにとって大切な場所なのに、計画のないまま 放置されていたし、彼自身ムゼウム通りはアムステルダムを分断していると感じていたと 述べる。また、オランダの新聞は読者に対して「最も醜い建築を選ぶコンペテイション」 や建築や都市計画への意見を求めることはあるが、彼の行ったような真剣な競技設計 を新閆が主催することは当時としても珍しかった述べている。面談 2006 年 9 月。

70) Arend Evenhuis, Plein gezocht en niet gevonden, Troun, 3- 11- 1988.

72）ファン・ローイの製作した番組は 1999 年にテレビ局 AVRO で放映された。1988 年 の NRC 紙による競技設計の入賞者、入賞はしなかったが興味深い提案者（作曲家 や森林愛護者、巨大駐車場案など)、またその後に提案を出したハイネケン（ハイネ ケンビール専属の建築家が解説）ヴエバー、建築家 W. Arets、当時の SMA 館長フク ス等が出演している。入賞作品は基本的に AMP 空間を開放的されたオープンスペー スとするものが選ばれている。水、緑、石など様々な素材で構成される空間や、夜に なると光で広場が浮かび上がる案の他、旧自動車道を強調し現状を批判的に取り扱う ものなどがある。また、鳥のための聖域とか、2000人が鑑賞できる野外オぺラハウス、 パリのルーブル美術館の前のガラスのピラミッドを建てるべきだと述べる者もいる。W Arets はこの周りに高層ビルを建てたいと言い、フクスはサンティアゴにあるような広場か いい上述べる。また、エベリンクの記憶によるとOMA（オランダ語で omaはおばあさん） は自らの事務所名ををもじって屋根の上に大きくOMA と書かれた高歯者用ケアハウス を提案し、他にオベリスクを建てる案もあったと述べている。

73) Ideeën voor een plein 28 oktober-27november, Stedelijk Museum, pp. 1-8. 競技設計の展 覧会時に配布された新聞紙形式のパンフレット。選評や入賞作が掲载されている。

74)フールトセンは、マーストリヒト市の歴史地区の都市計画に関りながら、当時の都心再 生といら理由のスクラップ\&ビルドの風潮に対して、19 世紀後期に造られた都市空間 の豊かさを訴える講演を方々で行っていた。オランダにとって19世紀的近代都市建 設は短い期間であったし、その価值の 1 つが皆が集まる為の広いパブリックスペース や都市緑地のネットワークだが 70 年代頃までは重要視されていなかったと述べている。

75) Frans Peeters, A.H. Heinekenplein, Het PAROOL, 1- 4- 1989.

76) Tanja van Bergen, Een echt contragewicht voor het Rijksmuseum, Het PAROOL 13-6-1989.

77) Gerrit van der Plas, Amsterdam heeft de open ruimte van het Museumplein hard nodig, Het PAROOL, 28-8-1989.

78) Brieven Museumplein, NRC-Handelsblad, 23-6-1988 ではヴェバー案は CG 周辺にあ まり配慮が見られず、この部分が祝福された空間（ヴェバー自身の解説から引用し） となっていないと述心、「ヴェバーが設計者として選ばれたことをどう思うか」という問い を6 月 14 日にし、6 月 23 日の投稿欄に 2 名分の批判的な意見を載せている。また Gerrit van der plas, Amsterdam heeft de open ruimte van het Museumplein hard nodig, $\mathrm{He}$ Parool, 28-8-1989 は、建物を建てることでなく空間に配慮すべきだから、SM 拡張部が もう少し小さい方がいいと指摘している。

79) Annemiek Paping, Stedelijk en van Gogh willen uitbreiden- Grooste plannen voor $\mathrm{Mu}$ seumplein. Telegraaf, 5-Okt-1989.に掲載された市の助役 M. Luimstra の見解。

80) アムステルダム市の行政区は1981 年にNoord とOsdorpの2地区が導入されて以来、 何度か分割再編が行われており、南区の発足した 1990 年には 10 以上の分割が行わ れた。現在は 14 の区とアムステルダム中央区が管轄する1地域の計 15 地区に分かれ ている。各区は以前の市が持っていた多くの権限を受け継いだが、その中には区内の 建築物建設等や都市開発、文化政策等の権限も含まれている。

81) Amsterdam Stadsdeel Zuid, Communicatieplan Herinrichting Museumplein, Amsterdam Stadsdeel Zuid, 1994, p. 2. アムステルダム市アーカイブ所蔵。

82) ホスパーは 都市計画等の大規模な計画にも関わったことのあるランドスケープアーキ テクトで、1997年に他界した。

83)フールトセン、クロースによると、自分たちがアーバンデザイン、ランドスケープ、建 築といら異なる分野の専門家で、また大学、役所といったどの機関にも属さず、フリー ランスで活動するものだといらことが重要だったと答えている。面談 2006 年 9 月。

84) ホスパーはすでに他界している為かなわかったが、残る諮問委員のフールトセンとク ロースと面談した。この章の内容はその面談による。最終的に残った候補者はアンデ ルソンとスペインの Beth Gali の2 名だった。また、委員会は、アンデルソンの補佐を ガル個人に頼んだという。フールトセンは彼が困難な仕事をやり遂げていることを知っ ていたので頼んだと述べ、ガルも彼が依頼された理由はAMPを必ず完成させるという 意思が南区と委員会にあったからだろうと述べている。

85) ARCAM は、1993 年の公開討説明会の議事録やアンデルソン案に対して寄せられ た意見を南区がまとめたものを所藏している。その中にはAMP 近辺の公的施設、商店、 交通関係協会の他、市民運動化家や個人からの意見や質問がある。批判し、全く新 たな案を提示するものもあれば、それほど否定的でないもの、質問、要望を伝えるも のもある。1993 年に関してはそれらに対する、アンデルソンとガルからの返答も残され ている。

86) Amsterdamde Raad voor de Stadsontwikkeling, Over de STEDEBOUWKUNDIGE PLANNEN VOOR HET MUSEUMPLEIN, ARS-advies nr. 156, Amsterdam, 1993, p. 1, に諮問委 員会としての 10 の意見（結論）をまとめている。他の意見の概略は、3.今後各文化 施設は AMP 上の遊歩道に何らかの慗がりを考えるべきだ。4. 交通問題解決のために A'dam 市に追加資金を要請する。5.バス専用の駐車場の数の增加要求。7. 歩道亡自 転車道を確保すること。8. 将来的な地下鉄入口の位置を明記してほしい。9. 今後、 国立博物館の拡張をする場合はAMP のデザインに配虑するべきだ。10．旧市街地 への車の入場制限法の成立に期待している。

87) アンデルソン案に関しては、図面や写真史料の他、ARCAM 所藏の1993 年3月 10、11 日に行われたマスタープランについての公開説明会の議事録やAMP 計画諮 問委員との手紙のやりとり等の資料に加え、ガルからの聞き取りを行った。

88) ガルは、AMP 上の RM、CG からの既存の軸性に加え、最も大きく、またどこにも 収束しない 3 本目の軸性を設けることで、バロックの軸性を打ち消したと述べている。3 本あればそれ以上のこの空間に及ぼす都市の要素からの軸線は絶対軸にはなりえな い。加えて、これは非常に民主主義的とも言える空間性だが、これはアンデルソンの 世代にとっては大切な意味があることでだ、とも述べている。

89)ガルは、例えば、黑川のVGMの新棟は、展示室だけれども、その形からはガスタ ンクかもしれないし映画館にも見える。三角形のドンキーイヤーも、今は駐車場の入り ロだけれども、店舗にも、休憩所にも、停留所にもなれてしまうように、形がある事柄 や意味を特定せず、見る人によってどのようにも理解の可能性がある点を指して、「抽 象」、つまり「何でもなく、何にでもなれる」場所と説明した。

90) 黒川案との折衝については、フールトセン、クロース、ガルとの面談にて、ヴェンチュー リ案との折衝についてはガルからの聞き取りによる。

91) 結局シザ案も 2002 年には立ち消え、2004 年の再度の競技設計で Benthem Crowe が選ばれた。今までの案は予算等を理由に棄却されているが、理由はそれだけで はなく、色々な批判があったことや、SMA 館長が、W. Beeren(1985-1993)、フクス (1993-2003)、H. van Beers (2003-2005) と3 度変わったことも理由と考えられる。

92) 1993 年 3 月 10 日付けの SMA 館長フクスの意見には、ムゼウム通りの時と比べて(ア フデルソンの）計画の方向性は変化して㧍らず、またドンキーイヤーが SMAをAMP の外に押しやり、見えなくしていると述べている。ARCAM 所蔵。

93) 1996 年 2 月 9 日にアンデルソンが AMP 計画の諮問委員に協力を要請して宛てた手 紙の内容。SMA と地下駐車場の開発業者のING 銀行がシザにドンキーイヤーを無視 していいと許可したようだと記されている。またシザの駐車場の入口の代替案は高額て あるうえに、駐車場としては効率の良い計画ではなく、初期に認められた予算内で行つ てきたマスタープランや、計画を推進するために為に行った交渉や調整が総て台無し になる案だと記されている。また、代替案が受け入れられるとは考えにくく、市民に肯 定的に受け入れられてきたマスタープランが害現しなかったら、市民の意志に反すると 確信していると記されている。ARCAM 所藏。

94) ガルより聞き取り。

95) Het nieuwe Museumplein, Het PAROOL, 22-8-1999.

96) 1993 年 3 月 10 日に行われたマスタープランについての公開説明会の議事録中の、 「AMP は何か」という質問に対するアンデルソンの返答、p.13、ARCAM 所藏。また、 ガルは聞き取りにて、AMPをあえて言い表すなら「フィールド」と表現した。

\section{図版出典}

Fig. 1 Stedelijk Museum,opnieuw stedelijk museum,2006, the cover Fig. 2 ed.Allard Jolles, op.cit., 1974, p. 92. に筆者が加筆。

Fig. 3 Simon Sadler, op.cit., p. 21

Fig. 4 Mark Wigley, op.cit. p. 180

Fig. 5, 6, 7, 8, 9 Hans Ebberink, Birgitte de Maar, op.cit., p. 42, p. 47, p. 51

Fig. 8 Amsterdam Stadsdeel Zuid, op.cit., p. 9.

Fig. 9 Hans Ebberink \& Birgitte de Maar, op.cit., p. 37.

Fig. 10 筆者撮影 2005 .

Fig. 11 Ideeën voor een plein 28 oktober-27november Stedelijk Museum, pp. 2-3 上り拔粋。 1988 年の競技設計の展覧時に配布された、競技設計の結果や審查員評の載つた冊子。 Fig. 12 Arend Evenhuis, Plein gezocht en niet gevonden, Trouw, 3-11-1988.

Fig. 13 Frans Peeters, A.H. Heinekenplein, Het PAROOL, 1- 4- 1989.

Fig. 14 de Architekten Cie, MUSEUMPLEIN, May 1989. C. Weeber 案原本の複写。 ARCAM 所藏。

Fig. 15 Weeber noemt plan voor Museumplein rommelig, Het PAROOL, 4-12-1990.

Fig. 16 Hemme Battjes, Het Museumplein, Staddeel Zuid, 1996,p. 12 に筆者が加筆。 